\title{
Self Efficacy dan Prestasi Belajar Siswa Dalam Pembelajaran IPA-Kimia
}

\author{
Hairida $^{1}$ dan Marhaeny Wiji Astuti ${ }^{2}$ \\ ${ }^{1}$ Pendidikan Kimia, FKIP Universitas Tanjungpura \\ ${ }^{2}$ SMP N 11 Kota Pontianak, Dinas Pendidikan Kota Pontianak
}

\begin{abstract}
Abstrak
Penelitian ini bertujuan untuk menentukan hubungan antara self efficacy dan prestasi belajar IPA-Kimia siswa SMP, sehingga metode penelitian yang digunakan adalah metode kuantitatif yang bersifat korelasional digunakan. Teknik pengambilan sampel secara random dengan peng-undian, terpilih sampel penelitian sebanyak 72 orang. Sebelum dilakukan analisa data, terlebih dahulu dilakukan uji persyaratan terhadap data hasil penelitian, yang meliputi uji normalitas dan linieritas. Pengujian statistik menggunakan uji Pearson Correlation dengan bantuan komputer program SPSS versi 17.0 for windows diperoleh nilai $r=0,858$ dengan $\rho=0,001$ berarti Ho ditolak. Disimpulkan, terdapat hubungan positif dan signifikan antara self efficacy dengan prestasi belajar IPA-Kimia. Dengan perkataan lain, semakin tinggi self efficacy maka semakin tinggi prestasi belajar IPA-Kimia siswa, sebaliknya semakin rendah self efficacy semakin rendah prestasi belajar siswa. Implikasinya, bagi para pengajar diharapkan dapat menciptakan suasana atau lingkungan belajar yang kondusif untuk peningkatan self efficacy siswa
\end{abstract}

Kata kunci: self efficcy, ipa-kimia

\section{Pendahuluan}

Pendidikan merupakan salah satu sektor penting dalam peningkatan kualitas bangsa. Hal ini tercermin dalam fungsi dan tujuan pendidikan nasional, yaitu mengembangkan kemampuan dan membentuk watak serta peradaban bangsa yang bermartabat dalam rangka mencerdaskan kehidupan bangsa, bertujuan untuk berkembangnya potensi peserta didik agar menjadi manusia yang beriman dan bertakwa kepada Tuhan Yang Maha Esa, berakhlak mulia, sehat, berilmu, cakap, kreatif, mandiri, dan menjadi warga negara yang demokratis serta bertanggung jawab. Jadi pendidikan itu penting bagi masyarakat Indonesia untuk mencerdaskan kehidupan bangsa agar menjadi bangsa yang berkualitas.

Mengingat pentingnya pendidikan, maka pendidikan perlu mendapatkan perhatian yang cukup besar dari pemerintah. Berbagai upaya sudah dilaksanakan oleh pemerintah bersama kalangan swasta untuk mengadakan berbagai perbaikan dalam bidang pendidikan. Perbaikan yang telah dilakukan antara lain melalui perubahan atau revisi kurikulum dan sistem evaluasi sekolah, pengadaan sarana sekolah yang memadai, berbagai penataran, sosialisasi dan pelatihan bagi guru dan tenaga kependidikan, peningkatan kualifikasi tenaga pendidik. Upaya yang dilakukan pemerintah ini ditujukan untuk mencapai tujuan pendidikan nasional, sehingga dapat ditingkatkan kualitas bangsa.

Untuk meningkatkan kualitas bangsa, IPA merupakan satu diantara mata pelajaran yang diperlukan siswa. Melalui mata pelajaran IPA, diharapkan siswa tidak hanya menguasai konsepkonsep IPA, melainkan dapat memecahkan masalah yang berkaitan dengan IPA. Untuk itu diperlukan kemampuan berpikir kritis, logis dan sistematis pada siswa. Kemampuan ini dapat dimiliki oleh siswa dalam pembelajaran IPA yang berkualitas. Namun di sisi lain, kualitas pendidikan IPA masih sangat rendah. Dari segi kualitas pendidikan, posisi Indonesia jauh 
tertinggal dengan negara-negara lain, bahkan lebih tertinggal dibandingkan dengan negara-negara ASEAN seperti Malaysia.

Hasil studi mengenai kualitas akademik siswa yang melibatkan 41 negara menunjukkan bahwa dalam bidang Ilmu Pengetahuan Alam (IPA), posisi Indonesia berada pada peringkat ke-38, sedangkan dalam bidang Matematika dan kemampuan membaca berada pada peringkat ke- 39 (Wayan Koster, 2006:501). Posisi ini berada jauh di bawah nilai rata-rata dunia. Sementara negara tetangga, yaitu Malaysia yang pernah belajar pada Indonesia dalam bidang pendidikan, berada di atas nilai rata-rata dunia. Gambaran buruk mengenai kualitas pendidikan Indonesia yang rendah juga tampak dari standar kelulusan siswa dalam Ujian Nasional (UN). Badan Standarisasi Nasional Pendidikan (BSNP) pada tahun 2011 menetapkan angka 5,5 dari skala kelulusan 10 untuk syarat kelulusan. Hal ini berarti kemampuan siswa menyerap pelajaran hanya 50,5 .

Untuk meningkatkan keberhasilan siswa dalam belajar IPA, peran dan tanggung jawab guru pada masa mendatang akan semakin kompleks. Mengetahui karakteristik siswa misalnya self efficacy, menjadi sangat penting untuk dipertimbangkan guru, sebagai salah satu faktor yang mempengaruhi keberhasilan siswa dalam belajar. Self efficacy adalah keyakinan seseorang bahwa dirinya akan mampu melaksanakan tingkah laku yang dibutuhkan dalam suatu tugas. Pikiran individu terhadap self efficacy menentukan seberapa besar usaha yang akan dicurahkan dan seberapa lama individu akan tetap bertahan dalam menghadapi hambatan atau pengalaman yang tidak menyenangkan. Self-efficacy bukanlah sebuah pengukuran keterampilan, tetapi mempercayai yang dilakukan dengan yang dimiliki dalam berbagai situasi (Bandura, 1997:37), sehingga tinggi rendahnya self efficacy siswa berkaitan dengan optimisme siswa dalam menyelesaikan tugas-tugas yang diberikan guru.

Self-efficacy mempengaruhi pilihan tugas individu, tenaga, ketekunan, dan prestasi (Schunk dan Meece, 2005:73). Siswa yang memiliki self-efficacy rendah untuk belajar mungkin menghindari tugas; sedang siswa yang menilai keyakinan dirinya tinggi lebih mungkin berpartisipasi"( Schunk, 1990: 71-86). Siswa yang melibatkan diri dalam aktifitas belajar mengamati performansi mereka sendiri yang mempengaruhi perasaan self-efficacy mereka. Ketika siswa mengamati kesuksesan dan menghubungkan kesuksesan dengan kemampuan mereka sendiri, self efficacy mereka meningkat. Sedangkan ketika mereka percaya bahwa mereka kurang mampu, dan mereka merasa tidak dapat mencapai kemampuan mereka sendiri, mungkin tidak termotivasi untuk bekerja (belajar) lebih keras.

Siswa yang memiliki self efficacy tinggi dalam IPA-Kimia, belajar atau melakukan tugas secara kompeten cenderung untuk berpartisipasi lebih mudah, tekun, bekerja lebih keras, mengerahkan segenap tenaga ketika mencoba suatu tugas atau soal, bertahan lebih lama ketika menghadapi kesulitan, gigih berusaha dan tangguh terhadap kesulitan. Sebaliknya, Self Efficacy rendah dalam IPA-Kimia, siswa mudah menyerah atau putus asa dalam menghadapi tugas yang sulit. Hal ini tentunya akan mempengaruhi prestasi siswa dalam belajar IPA-Kimia.

Dalam pembelajaran IPA-Kimia, seringkali ditemukan siswa tidak mampu menunjukkan prestasi akademis secara optimal sesuai dengan potensi yang mereka miliki. Ketidakmampuan ini dapat disebabkan siswa tidak percaya diri atau ragu-ragu dalam bertindak. Siswa merasa pesimis dan tidak yakin bahwa dirinya akan mampu menyelesaikan tugas-tugas yang diberikan guru. Akibatnya, siswa 
melakukan kecurangan untuk memperoleh suatu keberhasilan, misalnya menyontek. Dalam sebuah studi menyebutkan bahwa lebih dari 50 persen dan terkadang hingga 80 persen para siswa dan mahasiwa dilaporkan pernah menyontek (Rendra, 2008). Hal ini menunjukkan bahwa self efficacy merupakan salah satu faktor prediktif yang dapat mempengaruhi keberhasilan siswa dalam belajar.

Self efficacy rendah dapat terjadi karena seseorang belum mengenal potensi dirinya dan hambatan-hambatan dalam pengembangan potensi diri tersebut. Pengembangan diri harus diawali dengan pengenalan diri, salah satu caranya adalah melalui pengukuran potensi diri. Pengenalan diri akan membantu individu melihat kemampuan yang ada pada dirinya, mengetahui hal-hal yang berkembang dengan hal-hal yang masih perlu dikembangkan. Seseorang yang cenderung berprestasi rendah pada suatu mata pelajaran, dapat menyebabkan orang tersebut tidak percaya diri atau memiliki perasaan tidak mampu dalam menyelesaikan suatu masalah.

Menurut Bandura, pengukuran SelfEfficacy yang dimiliki seseorang mengacu pada tiga dimensi yaitu: level (tingkatan), generality (umum) dan strength (kekuatan) (1997: 42-43). Setiap dimensi ini memberi implikasi penting bagi performen seseorang. Level berkaitan dengan tingkat kesulitan yang di yakini oleh seseorang untuk dapat di selesaikan, streght berkaitan dengan kuat atau lemahnya keyakinan seseorang terhadap kesulitan tugas yang dapat dikerjakan, dan Generality menunjukkan apa-kah keyakinan akan berlangsung dalam domain tertentu atau berlaku dalam berbagai macam aktifitas dan situasi.

Bekerja dalam IPA-Kimia diperlukan ketelitian, keuletan, ketekunan dan pantang menyerah. Materi ilmu kimia yang cukup banyak, materi dasar (atom, molekul dan ion) yang tidak tampak atau abstrak dan ilmu kimia merupakan penyederhanaan dari yang sebenarnya, kadangkala menjadi kesulitan bagi siswa untuk mempelajarinya. Selain itu, belajar IPA-Kimia tidak sekedar belajar informasi IPA-Kimia tentang fakta, konsep, prinsip, hukum dalam wujud 'pengetahuan deklaratif', akan tetapi belajar IPA-Kimia juga belajar tentang cara memperoleh informasi, cara dan teknologi bekerja dalam bentuk pengetahuan prosedural, termasuk kebiasaan bekerja ilmiah dengan metode ilmiah dan sikap ilmiah. Siswa akan kesulitan jika belajar kimia hanya dengan menghafal saja. Diperlukan pemahaman konsep yang benar dan mendalam pada ilmu kimia. Oleh karena itu, dalam belajar IPA-Kimia diperlukan self efficacy yang cukup memadai. Semakin tinggi self efficacy siswa, semakin giat dan tekun usahanya dalam mencapai kesuksesan belajar IPA-Kimia. Ketika menghadapi kesulitan, siswa tersebut tidak mengurangi usaha-usahanya atau menyerah sama sekali terhadap kesulitan yang ada. Sebaliknya, ketika menghadapi kesulitan, siswa yang memiliki self efficacy rendah, keraguan dirinya semakin besar tentang kemampuannya, akan mengurangi usaha-usaha atau menyerah sama sekali.

Hasil penelitian Hadi Warsito (2004) menunjukan bahwa terdapat hubungan kausal positif signifikan antara SelfEfficacy dengan prestasi akademik. Hasil selanjutnya juga menemukan bahwa SelfEfficacy berhubungan kausal baik secara langsung maupun secara tak langsung dengan prestasi akademik. Sebaliknya, penelitian Powers (1991) dan Vancouver dkk (2002) (dalam Tahalele, 2005) menemukan adanya hubungan yang negatif antara Self-Efficacy dan prestasi akademik seseorang. Hasil penelitian keduanya ini sangat berbeda dengan hasil penelitian Warsito (2004) di atas. Adanya perbedaan ini menarik untuk diteliti lebih lanjut untuk melihat hubungan antara Self-Efficacy dengan prestasi akademik.

Mencermati permasalahan di atas, maka perlu dilakukan penelitian untuk 
menggambarkan secara jelas tentang adanya hubungan self efficacy dan prestasi belajar siswa dalam IPA-Kimia. Melalui penelitian ini, diharapkan akan diketahui secara jelas seberapa kuat hubungan antara self efficacy yang dimiliki siswa dan prestasi belajar IPAKimia siswa SMP Pontianak, sehingga hasil penelitian ini dapat digunakan para guru atau lembaga terkait sebagai acuan dalam meningkatkan kualitas pendidikan.

\section{Metode Penelitian}

Penelitian ini menggunakan metode kuantitatif yang bersifat korelasional, karena penelitian ini bertujuan untuk melihat hubungan antara variabel bebas (self efficacy) dan variabel terikat (prestasi belajar IPA-Kimia). Sesuai dengan tujuan penelitian, populasi terjangkau dalam penelitian adalah siswa kelas VII SMPN 11 Pontianak pada semester gazal tahun pelajaran 2012 dan 2013. Hasil pengujian menggunakan uji Barlett diperoleh bahwa ketujuh kelas adalah homogen, sehingga pengambilan sampel menggunakan teknik random sampling dengan pengundian. Terpilih dua kelas, yaitu kelas $F$ dan $G$ sebagai sampel penelitian.

Pengumpulan data penelitian dengan menggunakan instrumen tes dan nontes. Variabel hasil belajar dikumpulkan dengan menggunakan instrumen tes hasil belajar IPA-Kimia dengan bentuk uraian, sedangkan variabel self efficacy dikumpulkan dengan menggunakan instrumen non-tes berbentuk angket skala Likert. Instrumen tes hasil belajar dan self efficacy dikembangkan sendiri. Sebelum pelaksanaan penelitian, dilakukan validasi isi dan uji coba untuk menentukan reliabilitas terhadap tes dan angket.

Untuk menentukan koefisien validitas isi terhadap tes dan angket digunakan formula Gregory. Pakar memeriksa kesesuaian indikator dalam kisi-kisi dengan Standar Kompetensi dan Kompetensi Dasar/materi dan kesesuaian indikator dalam kisi-kisi dengan butir soal. Hasil penilaian dari kedua pakar dimasukkan ke dalam tabulasi silang $(2 \times 2)$ yang terdiri dari kolom A, B, C, dan D. Validitas isi adalah kolom D dibagi dengan $\mathrm{A}+\mathrm{B}+\mathrm{C}+\mathrm{D}$ (Gregory, 2011: 12). Hasil perhitungan diperoleh koefisien validitas sebesar 0,98 untuk kesesuaian indikator dalam kisi-kisi dengan Standar Kompetensi dan Kompetensi Dasar/materi dan 0,90 untuk kesesuaian indikator dalam kisi-kisi dengan butir soal. Simpulan yang didapatkan adalah bahwa butir instrumen sudah layak untuk digunakan. Berdasarkan hasil penilaian dan masukan-masukan yang diberikan pakar, butir-butir soal tersebut direvisi. Setelah direvisi, selanjutnya dilakukan ujicoba butir soal.

Hasil uji coba dianalisis untuk menentukan validitas per item dan reliabilitas tes. Validitas tes hasil belajar IPA-Kimia dihitung menggunakan point biserial. Hasil perhitungan ditemukan butir soal yang tidak valid, yaitu butir soal 6, 36, 42 dan 46. sehingga banyaknya butir soal pada tes hasil belajar IPA-kimia yang digunakan sebagai instrumen penelitian adalah 46 butir. Sedangkan reliabilitas tes dihitung menggunakan Kuder-Richardson KR-21. Hasil perhitungan reliabilitas butir tes hasil belajar IPA-Kimia diperoleh harga sebesar 0,81 dengan kategori tinggi.

Kisi-kisi instrumen self efficacy disusun berdasarkan konstruk yang disintesiskan dari teori-teori yang mendukung variabel self efficacy. Jumlah item sebanyak 41 butir, terdiri dari 21 item favourable dan 20 item unfavourable. Dari hasil analisis faktor yang digunakan dalam penelitian ini, yaitu analisis faktor penegasan (comfirmatory factor analysis) diperoleh koefisien eigenvalue lebih besar dari 1,00 sebanyak tujuh faktor, dengan hasil analisis yaitu: 16,$656 ; 5,870 ; 3,548$; 2,$291 ; 1,543 ; 1,372$; dan 1,083 dengan kumulatif sebesar 85,163\%. Berarti 
ketujuh faktor tersebut telah dapat mengukur variabel yang seharusnya diukur, yaitu self efficacy.

Hasil perhitungan reliabilitas instrumen self efficacy dengan menggunakan rumus Alpha Cronbach, diperoleh harga sebesar 0,92. Hal ini menunjukkan bahwa butir pernyataan angket mempunyai konsistensi yang tinggi. Berdasarkan hasil uji coba angket, diperoleh perubahan jumlah item pernyataan angket self efficacy, yaitu sebelum uji coba terdapat 41 item, setelah uji coba terdapat 38 item pernyataan angket.

Teknik analisis data dalam penelitian ini terbagi atas dua bagian, yaitu: analisis deskriptif dan analisis inferensial. Analisis deskriptif berupa cara-cara pengumpulan data, penyederhanaan angka-angka pengamatan yang diperoleh (meringkas, dan menyajikan), serta melakukan pengukuran pemusatan dan penyebaran data untuk memperoleh informasi yang lebih menarik, berguna dan mudah dipahami. Sedangkan analisis inferensial dengan menggunakan korelasi Pearson product moment adalah teknik analisis data yang digunakan untuk melihat hubungan antara self efficacy dan prestasi belajar IPA-Kimia. Cara perhitungannya dibantu dengan menggunakan program komputer SPSS (Statistical Product and Service Solutions)Release 17.0 For Windows. Sebelum dilakukan analisa data, terlebih dahulu dilakukan uji persyaratan terhadap data hasil penelitian, yang meliputi uji normalitas dan linieritas. Uji normalitas ber-tujuan untuk mengetahui apakah distribusi dari penenltiian masing-masing variabel, yaitu variabel bebas dan terikat telah menyebar secara normal. Uji normalitas sebaran dianalisis menggunakan KolmogorovSmirnov dengan bantuan SPSS for windows versi $17 . \quad \mathrm{Uji}$ linieritas digunakan untuk mengetahui apakah distribusi data penelitian, yaitu variabel bebas dan variabel terikat memiliki hubungan linier. Uji linieritas dilakukan dengan menggunakan analisa varians (ANAVA) dan Scatter Plot dengan bantuan SPSS for windows versi 17.

\section{Hasil dan Pembahasan Hasil}

Berdasarkan uji persyaratan pertama, yaitu uji normalitas pada kedua data (self efficacy dan tes) menggunakan metode kolmogorov-Smirnov diperoleh harga $\rho>0,05$. Pada data variabel self efficacy diperoleh $\rho=0,065$ dan data variabel prestasi beajar diperoleh $\rho=$ 0,070. Hasil kedua data ini menunjukkan bahwa penyebaran data variabel self efficacy dan prestasi belajar IPA-Kimia berdistribusi normal. Secara lengkap hasil pengujian dapat dilihat pada tabel 1 berikut ini.

Tabel 1. Uji Normalitas Data Self Efficacy dan Tes Prestasi Belajar

\begin{tabular}{|l|r|r|r|l|}
\hline \multirow{2}{*}{ Variabel } & \multicolumn{3}{|c|}{$\begin{array}{c}\text { Kolmogorov- } \\
\text { Smirnov }\end{array}$} & \multirow{2}{*}{ Keterangan } \\
\cline { 2 - 4 } & Statistik & df & \multicolumn{1}{|c|}{ Sig. } & \\
\hline $\begin{array}{l}\text { Self } \\
\text { Efficacy }\end{array}$ & .101 & 72 & .065 & $\begin{array}{l}\text { Sebaran } \\
\text { Normal }\end{array}$ \\
\hline Tes & .100 & 72 & .070 & $\begin{array}{l}\text { Sebaran } \\
\text { Normal }\end{array}$ \\
\hline
\end{tabular}

Selanjutnya dilakukan uji persyaratan kedua, yaitu uji linieritas hubungan. Uji linieritas dilakukan dengan menggunakan teknik interactive graph yang berupa diagram pencar. Berikut ini gambar diagram pencar dari data self efficacy dan prestasi belajar IPA-Kimia.

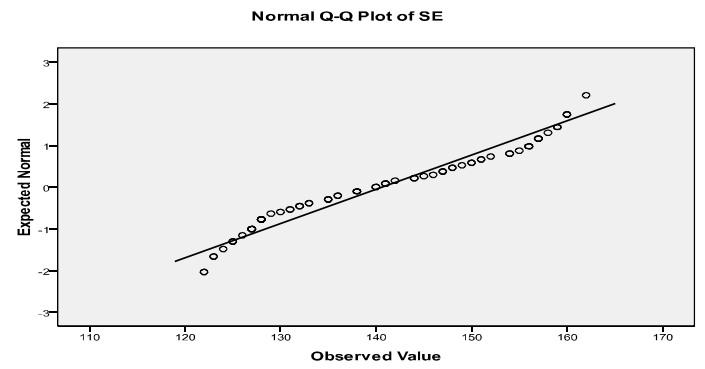

Gambar 1. Diagram Pencar Data Self Efficacy dan Prestasi Belajar IPA-Kimia 
Dari uji linieritas diperoleh harga $\mathrm{F}$ $(1,834)>\rho(0,037)$ berarti $H_{0}$ diterima, dengan demikian model regresi hubungan antara self efficacy dan prestasi belajar IPA-Kimia siswa berpola linier. Secara lengkap hasil dari pengujian linieritas tersebut dapat dilihat pada gambar 1 berikut.

Tabel 2. Uji Linieritas Data Self Efficacy dan Tes Prestasi Belajar

\begin{tabular}{|l|l|l|r|r|r|r|r|}
\hline & & \multicolumn{1}{c|}{$\begin{array}{l}\text { Sum of } \\
\text { Squares }\end{array}$} & df & Mean Square & \multicolumn{1}{c|}{ F } & Sig. \\
\hline THB * SE & $\begin{array}{l}\text { Between } \\
\text { Groups }\end{array}$ & (Combined) & 2354.333 & 34 & 69.245 & 9.791 & .001 \\
\cline { 3 - 8 } & Linearity & 1926.340 & 1 & 1926.340 & 272.387 & .001 \\
\cline { 2 - 8 } & $\begin{array}{l}\text { Deviation } \\
\text { from Linearity }\end{array}$ & 427.994 & 33 & 12.970 & $\mathbf{1 . 8 3 4}$ & $\mathbf{. 0 3 7}$ \\
\cline { 2 - 8 } & Within Groups & 261.667 & 37 & 7.072 & & \\
\cline { 2 - 8 } & \multicolumn{2}{l|}{ Total } & 2616.000 & 71 & & & \\
\hline
\end{tabular}

Kedua persyaratan, yaitu normalitas dan linieritas data sudah dipenuhi maka dapat dilakukan uji statistik menggunakan uji Pearson Correlation. Secara lengkap hasilnya sebagai berikut:

Tabel 3. Uji Korelasi Pearson

\begin{tabular}{|l|l|c|c|}
\hline Variabel & & Self Efficacy & Tes Prestasi Belajar \\
\hline \multirow{4}{*}{ Self Efficacy } & Pearson Correlation & 1 & $.858^{* *}$ \\
\cline { 2 - 4 } & Sig. (2-tailed) & & .000 \\
\cline { 2 - 4 } & $\mathrm{N}$ & 72 & 72 \\
\hline \multirow{2}{*}{$\begin{array}{l}\text { Tes Prestasi } \\
\text { Belajar }\end{array}$} & Pearson Correlation & $.858^{* *}$ & 1 \\
\cline { 2 - 4 } & Sig. (2-tailed) & .000 & 72 \\
\cline { 2 - 4 } & $\mathrm{N}$ & 72 & \\
\hline \multicolumn{2}{|l}{} \\
\cline { 2 - 4 }
\end{tabular}

Berdasarkan hasil pengujian statistik menggunakan uji Pearson Correlation dengan bantuan komputer program SPSS versi 17.0 for windows pada tabel 3 di atas diperoleh nilai $\mathrm{r}=$ 0,858 dengan $\rho=0,01$ untuk korelasi antara self efficacy dengan prestasi belajar IPA-Kimia siswa SMP. Hal ini menunjukkan bahwa hipotesa nol (Ho) ditolak dan hipotesa alternatif (Ha) diterima. Artinya, terdapat hubungan positif antara self efficacy dengan prestasi belajar IPA-Kimia. Dengan perkataan lain, semakin tinggi self efficacy maka semakin tinggi prestasi belajar IPA-Kimia siswa, begitu pula sebaliknya, semakin rendah self efficacy maka semakin rendah prestasi belajar IPA-Kimia siswa. Dari tabel 3 di atas juga menunjukkan bahwa nilai sig. $=0,000$, berarti nilai sig. $<0,05$, sehingga dapat disimpulkan bahwa variabel self efficacy dan prestasi belajar IPA-Kimia siswa memiliki hubungan yang linier.

\section{Pembahasan}

Hasil uji hipotesis menunjukan bahwa terdapat hubungan yang positif dan signifikan antara self-efficacy dan prestasi belajar siswa. Maka dapat disimpulkan bahwa prestasi belajar IPA-Kimia lebih dipengaruhi secara langsung oleh self efficacy. Hubungan yang positif dan signifikan tersebut menunjukan bahwa semakin tinggi self-efficacy siswa maka 
semakin tinggi pula prestasi belajar yang dicapai siswa. Hubungan ini menunjukkan bahwa tinggi atau rendahnya prestasi belajar siswa dipengaruhi tinggi atau rentahnya self-efficacy yang dimilikinya.

Berdasarkan teori-teori yang berkaitan denhgan self efficacy disimpulkan bahwa siswa yang memiliki self-efficacy yang tinggi, akan berusaha atau gigih dalam mencoba karena selfefficacy mempengaruhi pilihan tugas individu, tenaga, ketekunan, dan prestasi. Siswa yang memiliki self efficacy tinggi, dalam belajar atau melakukan tugas, secara kompeten cenderung untuk berpartisipasi lebih mudah, tekun, bekerja lebih keras, mengerahkan segenap tenaga ketika menghadapi suatu tugas atau soal yang sulit, bertahan lebih lama ketika menghadapi hambatan, dan mencapai pada tingkat yang lebih tinggi. Seseorang yang memiliki self efficacy tinggi, melihat hambatan sebagai tugas yang dapat diatasi, sehingga mereka gigih berusaha dan tangguh terhadap kesulitan. Sebaliknya seseorang yang memiliki self efficacy rendah, mudah yakin akan kesiasiaan usaha dalam menghadapi tugas yang sulit, sehingga mereka mudah putus asa, semangat untuk belajar kurang, atau menghindari tugas-tugas yang sulit.

Ilmu kimia dikembangkan berlandaskan percobaan (eksperimen) di laboraturium, serta melalui penerapan konsep-konsep matematika, sehingga ilmu kimia masih terus berkembang. Selain itu, berbagai teori dan temuan dalam IPA-Kimia direfleksikan dengan representasi makroskopis, mikroskopis, dan simbolis. Representasi merupakan bahasa bagi sains kimia. Ahli-ahli kimia mengguna-kannya untuk berkomunikasi dan untuk mengembangkan keterampilan berpikir, keterampilan proses atau metode ilmiah. Dengan demikian, untuk mempelajari ilmu kimia, diperlukan self efficacy yang cukup baik agar mudah dalam memahami materi-materi kimia. Pemahaman yang baik dalam belajar kimia, akan dapat meningkatkan prestasi belajar siswa. Dengan demikian pencapaian prestasi

akan semakin optimal dengan didukung self-efficacy. Jadi, jelaslah bahwa antara self efficacy dan prestasi belajar terdapat hubungan yang positif dan signifikan.

\section{Simpulan dan Saran Simpulan}

Berdasarkan hasil penelitian dapat disimpulkan bahwa terdapat hubungan yang positif dan signifikan antara self efficacy dan prestasi belajar IPA-Kimia siswa. Semakin tinggi self efficacy siswa, semakin tinggi pretasi belajar siswa, sebaliknya, semakin rendah self efficacy siswa, semakin rendah pretasi belajar siswa.

\section{Saran}

Berdasarkan kesimpulan bahwa adanya hubungan yang positif dan signifikan antara Self efficacy dan prestasi belajar siswa, maka bagi pengajar diharapkan dapat menciptakan suasana atau lingkungan belajar yang kondusif untuk peningkatan self efficacy siswa. Misalnya melalui stimulus berupa soalsoal/kasus-kasus yang menantang, pemberian penguatan atau feedback dari semua aktifitas yang sudah dilakukan siswa. Bagi guru Bimbingan dan Konseling, agar dapat memfasilitasi siswa melalui kegiatan-kegiatan yang dapat meningkatkan self efficacy siswa.

\section{Daftar Pustaka}

Bandura, Albert. 1997. "Perceived Self Efficacy in The Exercise of Control Over Aids Infection." Evaluation and Program Planning, Vol.13, 8-15. http://www.des.emory.edu/mfp/Ban dura1990EP.pdf (Diakses 23 April 2012).

Gregory, Robert J. 2011. Pschological Testing: History, Principles, and Aplications. Needham Height: Allyn and Bacon. 
Koster, Wayan. 2006. "Membangun Kemandirian dan Peradaban Bangsa Melalui Melalui Pendidikan." Jurnal Pendidikan dan Kebudayaan, No. 061, Juli, 2006, 501-511.

Rendra. 2008. "Nyontek, Pantang Buat Si Pemberani." Kompas, 18 Agustus 2008.

http://www1 kompas.com/lipsus082 009/rendraread/2008/08/18/143303 47/nyontek.pantang.buat.si.pembera ni (Diakses 6 Nopember 2011).

Schunk, Dale H., dan Judith L. Meece. 2005. Self E fficacy Development in Adoles-cences. Self-Efficacy Beliefs of Adolescents.", 7190.http://www.des.emory.edu6/mfp/
03SchunkMeeceAdoEd5.pdf (Diakses 23 April 2012).

Tahalele, D. Mirrela. 2005. Hubungan Antara Self-efficacy dengan Motivasi Berprestasi Karyawan. Program Studi Psikologi Fakultas Psikologi Universitas Kristen Satya Wacana Salatiga : Skripsi Tidak diterbitkan.

Warsito, Hadi. 2004. Hubungan Antara Self-Efficacy Dengan Penyesuaian Akademik Dan Prestasi Akademik. Jurnal Psikologi Pendidikan . Vol.2. September 2004. 
34 Jurnal Pendidikan Matematika dan IPA Vol. 3. No. 1. Januari 2012 